\title{
MIEJSCE ŚMIERCI i ZMARTWYCHWSTANIA CHRYSTUSA
}

Jak ze wszystkich miejsc całej Ziemi świętej najważniej-szym i najsłynniejszym miejscem jest święte miasto Jeruzalem, wysławiane i opisywane jùz przez natchnionych psalmistów i proroków, tak znów w samym Jeruzalem najczcigodniejszym miejscem jest to, na którym Chrystus dokonał odkupienia ludzkości przez ofiarę śmierci na krzyżu oraz miejsce grobu, z którego triumfalnie wyszedł po Swej krzyżowej śmierci. Miejsce Ukrzyżowania było kresem ziemskiego życia Chrystusa, miejsce zaś grobu, początkiem Jego chwalebnego życia.

W obu tych miejscach kończą w każdy piątek po południu O. O. Franciszkanie $z$ pobożnymi katolikami procesję Drogi Krzyżowej, w czasie której po wąskich uliczkach Jeruzalem pełni tradycyjną straż muzułmańska gwardia honorowa. Do obu tych miejsc zdążają chrześcijanie wszystkich wieków, nie zważając na trudy i niebezpieczeństwa podróży. Dla Polaków pielgrzymka do tych najdroższych pamiątek chrześcijańskich jest obecnie niezwykle trudna. Powodem tego jest fakt, że ta część Jerozolimy, która mieści te świẹte miejsca, jak i Betlejem należy do arabskiego państwa Jordanii. Między Ammanem zaś a Warszawą brak nie tylko stosunków dyplomatycznych, ale także brak wspólnej linii politycznej. Toteż gdy mimo trudności uda się pielgrzymowi z Polski znaleźć $\mathrm{w}$ arabskiej Jerozolimie, to $\mathrm{z}$ tym większą gorliwością kie- 
ruje swe kroki na miejsce Śmierci i Zmartwychwstania Chrystusa.

Nie można dziś oglądać Kalwarii, ani grobu w takiej postaci, jaką miały te miejsca w chwili Mẹki i śmierci Chrystusa, gdyż chrześcijanie oba te miejsca w ciagu wieków ozdobili wspaniałymi sanktuariami. Juz cesarz Konstantyn wzniósł obok Kalwarii wspaniałą bazylikę zwaną Martyrium Posiadała ona rozległe krużganki. Obok nich w południowowschodniej części mieściła się skała kalwaryjska z ozdobnym krzyżem na szczycie. Nad pobliskim zaś grobem wzniósł ce-

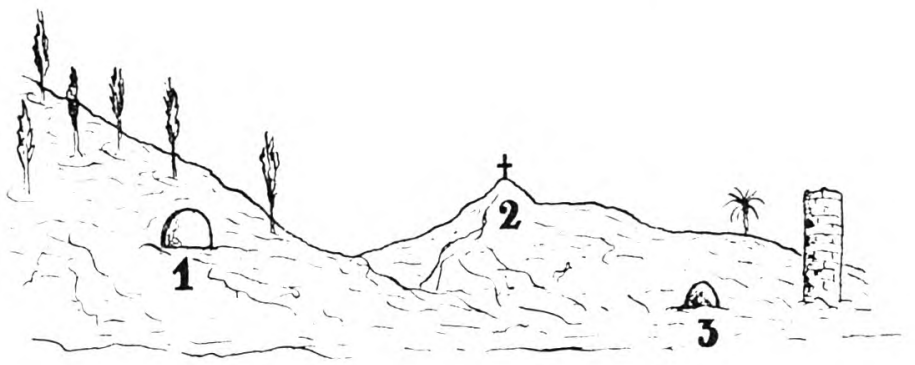

1. Grób Boży 2. Góra Kalwaria 3. Cysterna historyczna

sarz Konstantyn świątynię zwaną ..Anastasis" - ..Zmartwychwstanie", gdzie pod sklepieniem w kształcie kopuły mieściła sie skała z wykutym w niej grobem Chrystusa. Gdy wspaniałe budowle Konstantyna, zburzone cześsiowo przez persów (614), odnowione przez mnicha Modesta, zburzyli znów Arabowie W XI w. (1009), to w następnm wieku (1130-40) krzyżowcy wznieśli okazałą świątynię, którą czẹściowo przebudowali Grecy w XIX w. (1808). W świątyni krzyżowców zamkniẹto zarówno skałẹ Golgoty, jak i skałę Grobu Bożego. Pokryto je drogimi marmurami i wzniesiono nad nimi ozdobne kaplice tak, że pielgrzym współczesny z trudem tylko może sobie odtworzyć pierwotny obraz tych świętych miejsc.

Autentyczne miejsce śmierci Chrystusa znajdowało się kilka zaledwie metrów poza północno-zachodnią bramą miasta Jerozolimy. Było ono małym skalistym wzgórzem, wysokim 
na kilka metrów. Zwali je Żydzi w swym aramajskim języku Golgota, tj. wzgórzem Trupiej Głowy, być może ze wzglẹdu na kształt tego wzgórza, przypominającego żywej wyobraźni ludzi Wschodu kształt ludzkiej czaszki. U stóp tego wzgórza od strony północno-zachodniej znajdował się ogród Józefa $\mathrm{z}$ Arymatei $\mathrm{z}$ wykutym w skale grobowcem rodzinnym. Pisze o tym św. Jan w swej ewangelii: "A na miejscu, gdzie został ukrzyżowany był ogród, a $w$ ogrodzie grobowiec nowy, w którym jeszcze nikt nie był pochowany. Tutaj tedy, ponieważ grobowiec byz blisko, $z$ powodu $\dot{z} y d o w s k i e g o$ dnia
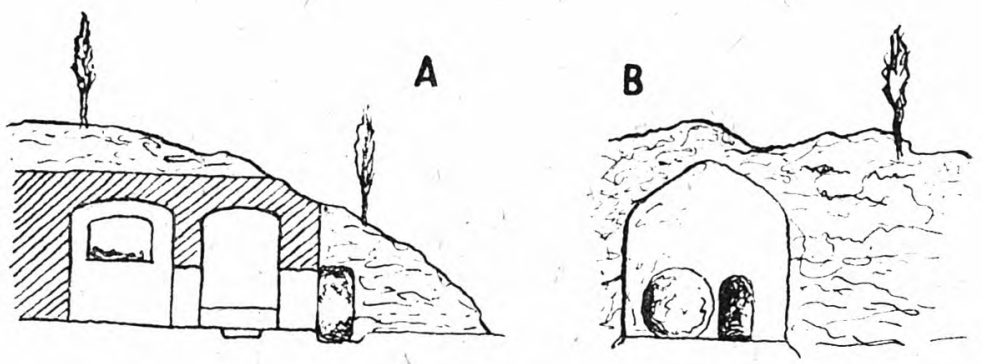

Grobowiec żydowski: A. W przekroju B. Kamień grobowy

Przygotowania pochowano Jezusa" (19, 41-42). Od strony zaś południowo-wschodniej wzgórza Golgoty znajdowała się. starożytna cysterna, gdzie w czasach Konstantyna znaleziono narzędzia męki Chrystusa i dwóch łotrów.

Grób Józefa z Arymatei nie różnił się niczym od innych współczesnych grobów żydowskich, których wiele odnaleziono w całej Palestynie. Wchodziło się najpierw do przedsionka, a stąd przez małe wejście do komory grobowej $\mathrm{z}$ ławą na zwłoki, którą wykuwano w skale. Wejście z przedsionka do komory grobowej zamykał okrąły kamień. Kamień grobowy przetaczać można było na prawo lub na lewo wzdłuż dwóch podtrzymywaczy, z których jeden był umieszczony w posadzce grobu, a drugi w jego suficie.

Przed wejściem do bazyliki Grobu Bożego znajduje się 
dziedziniec brukowany o wymiarach $25 \times 17 \mathrm{~m}$. Piękną fasade romańską dzisiejszej bazyliki szpeca żelazne umocnienia. Swiątyni bowiem od dłuższego czasu zagraża ruina. W wielkim tygodniu 1938 r. rząd angielski, sprawujący wówczas rządy w Palestynie obawiając się zawalenia, zabronił funkcyj publicznych w tej świątyni. Dziś także i wnẹtrze świątyni

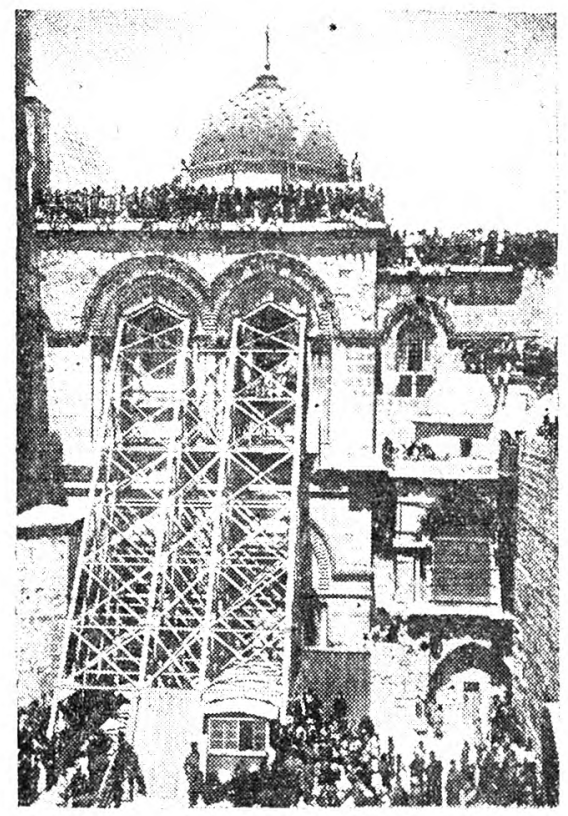

Fronton Bazyliki

zostało umocnione żelaznymi klamrami. Czyni się zbiórki w całym świecie chrześcijańskim, zarówno wśród Greków, jak i Eacinników, celem przeprowadzenia gruntownej restauracji tej świątyni. Prace przygotowawcze rozpoczęto w r. 1954.

Do świątyni Grobu Bożego wchodzi się dziś tylko przez jedną bramę, gdyż drugą zamurowano w czasach Saladyna. Również zamurowano od zewnątrz wejście na Kalwarię. Mieści się tu obecnie kaplica Franków, do której się wchodzi po 12 schodach od zewnątrz. 
Plan bazyliki Grobu Chrystusa jest mocno skomplikowany. Po przekroczeniu bramy, zaraz po lewej stronie przedsionka znajduje się kamienna ława, zasłana tureckim dywanem, dla muzułmańskich odźwiemych świątyni. Od czasów sułtana Saladyna aż po dzień dzisiejszy dziedzicznymi stróżami bazyliki są dwie rodziny arabskie Jude i Nussebe.

Plan obecnej Bazyliki

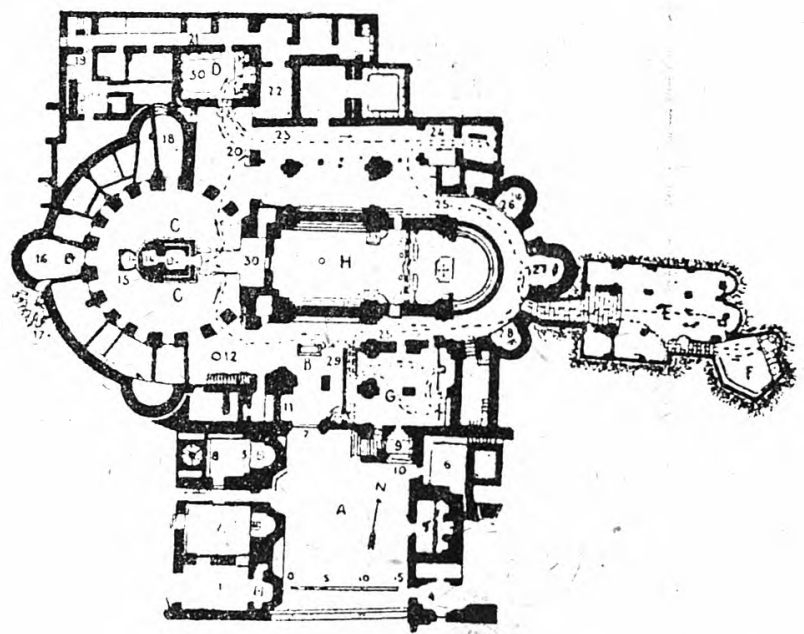

A. - Przedsionek. B. - Kamień Namaszczenia. C. - Kaplica Grobu Siw. D. - Kaplica Ukazania się Jezusa Swej Matce. E. - Kaplica św. Heleny. F. Kaplica Znalezienia Krzyża Św. G. - Kalwaria. H. - Chór grecki.

Wszedłszy $\mathrm{z}$ przedsionka do bazyliki należy skręcić na prawo, aby wyjść na Golgotę. Jeżeli zaś po wejściu do bazyliki idzie się prosto, to dochodzi się do chóru greckiego (katedry patriarchy greckiego). Na lewo od muru chóru greckiego znajduje się rotunda tj. okrągła świątynia, w środku której wznosi się grób Zbawiciela. Ponadto w bazylice znajdują się jeszcze inne liczne kaplice, oraz ołtarze, np. ołtarz namaszczenia Ciała Chrystusa po zdjęciu z krzyża, kaplica ukazania się Zmartwychwstałego Chrystusa, kaplica św. Heleny i św. Krzyża oraz wiele innych. 


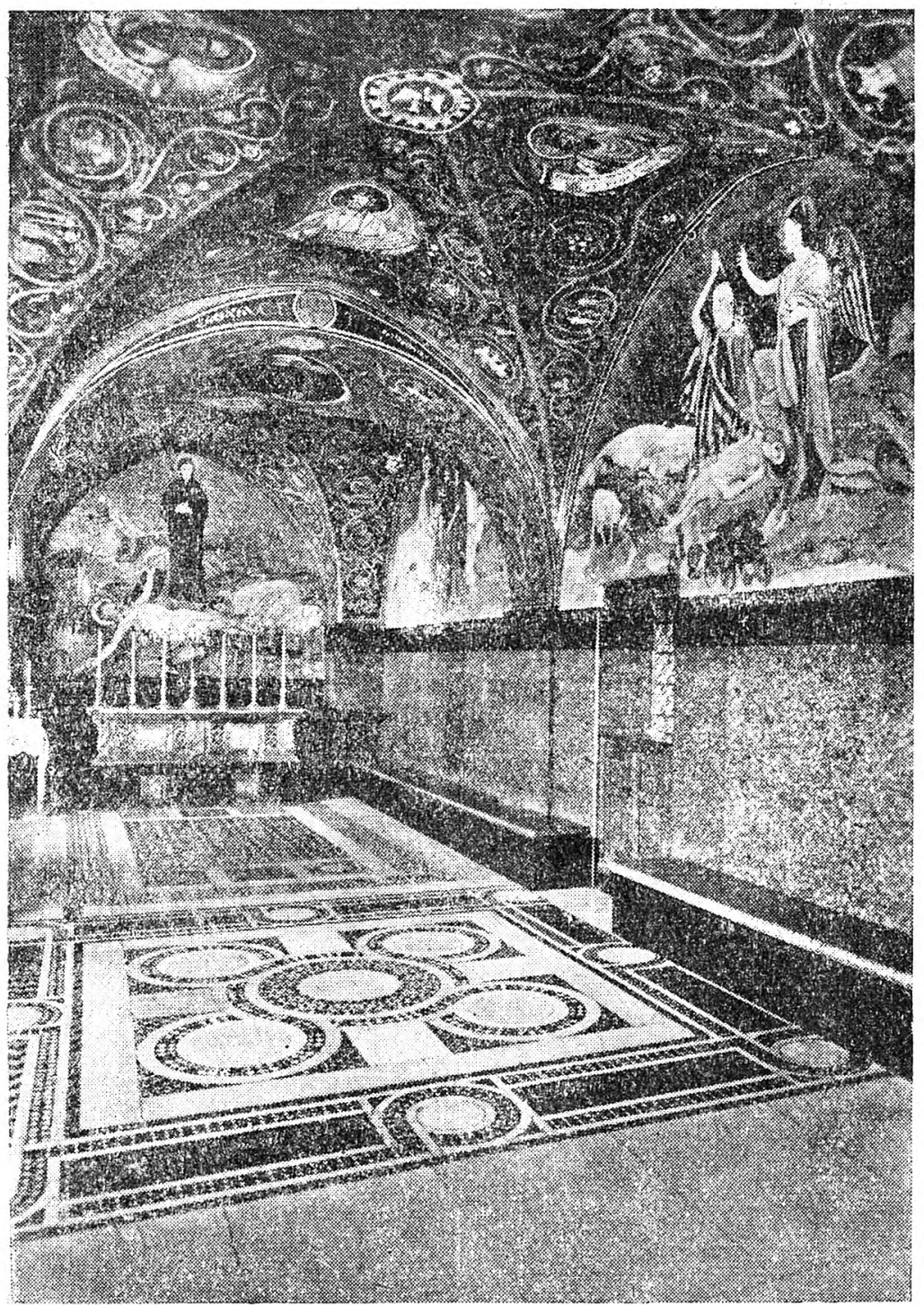

Kaplica Ukrzyżowania 
$\mathrm{Na}$ Golgotę wychodzi się schodami liczącymi 18 stopni. Nad dawną skałą kalwaryjską mieści się dziś kaplica, podzielona za pomocą dwóch wielkich filarów na dwie nawy, o wym. $11,5 \times 9 \mathrm{~m}$. Północna nawa należy do greckich schizmatyków, południowa do katolików. Miejsce, gdzie Pan Jezus był ukrzyżowany należy do Greków, co upamiętnia ołtarz bronzowy.

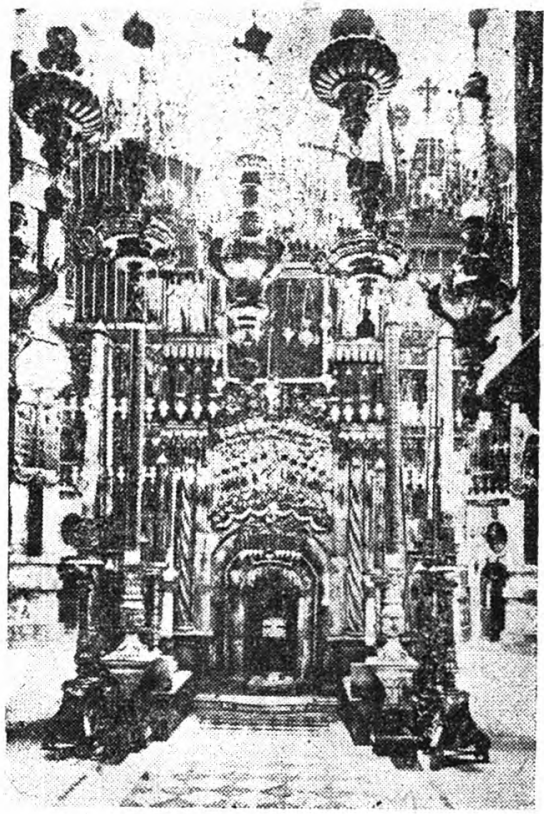

Kaplica grobu Chrystusa na Kalwarii

Między kolumienkami zaś podtrzymującymi mensę ołtarza: Ukrzyżowania znajduje się otwór, otbczony srebrną pozłacaną blachą. Jest to miejsce, gdzie stał krzyż Chrystusa: Można ręką dotknąć się tej świętej skały. Na prawo pokazuje się pionową rysę spowodowaną trzęsieniem ziemi, jakie miało miejsce po śmierci Chrystusa.

W nawie kaplicy należącej do Łacinników znajdują się dwa ołtarze, z których jeden upamiętnia przybicie Jezusa do krzy- 
ża, a drugi przypomina to miejsce, gdzie Maryja stała pod krzyżem swego Syna. Tu tylko moga kapłani katoliccy odprawiać mszę św. i ofiarować Majestatowi Bożemu tę Krew, która na tej Kalwarii przed wiekami złożył pierwszy Arcykapłan Nowego Przymierza. Przed miejscem śmierci Chrystusa mogą się katolicy tylko pomodlić i dotknać ze czcią świętej skały, którą.zrosiła krew Chrystusa.

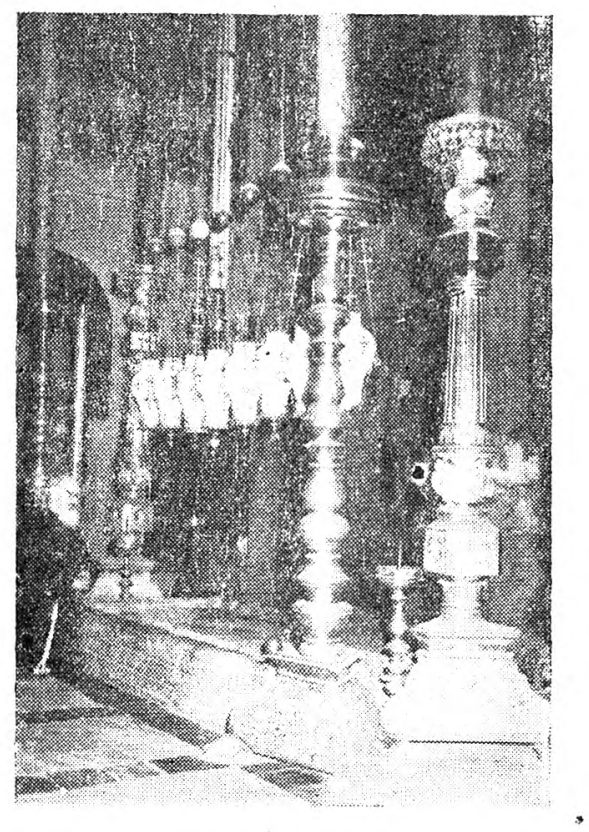

Kamień Namaszczenia P. Jezusa po zdjeciu z Krzyża

Pielgrzym, schodząc pełen świętej zadumy z Kalwarii, zatrzymuje się na chwilę przed ołtarzem Namaszczenia, gdzie pobożne niewiasty po zdjęciu Ciała Chrystusowego z krzyża namaściły je olejkami i owinęły w białe prześcieradła. Ołtarz ten należy do Eacinników, Greków i Ormian, którzy palą tu swe lampy i odprawiają nabożeństwa.

Jeżeli miejsce Golgoty jest miejscem powagi i smutku, to miejsce Grobu Chrystusa jest miejscem wesela i radości Ka- 
plica, która mieści grób święty, znajduje się pod wielką kopłą rotundy. Obecny grób Zbawiciela został odbudowany przez Greków w 1808 roku i ma kształt prostokątu o wymiarach $3,30 \times 5,90 \times 5,90 \mathrm{~m}$. Na szczycie znajduje się kopuła w stylu moskiewskim. Front kaplicy grobowej zdobią 4 kolumny i 3 obrazy. Przed każdym z nich płoną lampy, należące do Łacinników, Greków i Ormian.

Jak każdy grób żydowski, tak i grób Chrystusa składa się z dwu części. Posiada on przedsionek zwany dziś kaplicą Anioła, gdyż tutaj anioł oznajmił pobożnym niewiastom, że Pan Jezus zmartwychwstał. Posiada ona wymiary $3,9 \times 3,4 \mathrm{~m}$. We whętrzu jej znajduje się kamień grobowy pokryty pięknym marmurem. -

Wchodząc dọ właściwego grobu Chrystusa należy się dobrze schylić, gdyż wejście don, choć zostało podwyższone przez krzyżowców w r. 1133, wynosi tylko 1,33 m wysokości. Cela grobowa ma długość 2,02 m i 1,94 m szerokości. Dawna skała grobowa jest dziś pokryta białym marmurem; na prawo od wejścia do tej celi znajduje się płytka białego marmuru, pokrywająca to miejsce, gdzie leżało Ciało Pana Jezusa. Nad płytą grobową znajduje się ołtarz, w którym znajdują się trzy obrazy Chrystusa Zmartwychwstałego, z których jeden należy do Greków, drugi do Ormian, a trzeci do Łacinników. Przed ołtarzem tym wisi 15 lamp, z których 5 należy do Łacinników, 5 do Greków, 4 do Ormian i jedna do Koptów. Tu w wyznaczonych godzinach Grecy, Ormianie i Eacinnicy codziennie wysławiają cud Zmartwychwstania Chrystusa. Chrześcijanie obrządku koptyjskiego czynią to w przybudowanej do grobu Chrystusa małej kapliczce. Eacinnicy zaczynają swe nabożeństwa ranne o godz. 5-tej; o godz. 7-mej zaczyna się ostatnia Msza św. łacińska, w czasie której chór gregoriański ojców i braci Franciszkanów naprzemian z chłopcami arabskimi śpiewa codziennie wielkanocną wotywę: "Resurrexi“.

Jeżeli uroczystości rezurekcyjne w naszych kościołach budzą niezwykłą radość w sercach wiernych, to tym potężniej działa udział we Mszy św. rezurekcyjnej odprawianej przy 
grobie Chrystusa Pana. Odczuwa to każdy uczestnik tej Mszy św., a zwłaszcza kapłan, celebrujący ją. Jest przecież w tym miejscu, gdzie w niedzielę Wielkanocną przez zamknięty i zapieczętowany kamień grobowy wyszedł Chrystus, jako triumfator nad swymi wrogami. Nigdzie chyba na świecie nie przeżywa się tak głęboko tej prawdy historycznej, jaka jest Zmartwychwstanie Chrystusa, będące fundamentem wszelkiej naszej nadziei, a w szczególności nadziei naszego ostatecznego zwycięstwa nad złem i śmiercią i zmartwychwstania do życia wiecznego.

Ks. STANISEAW モACH 